\title{
TRADISI MEGALITIK PADA RITUAL KEKERIK DI KALANGAN MASYARAKAT TENGGER
}

\section{MEGALITHIC TRADITION IN THE KEKERIK TRADITION OF TENGGER COMMUNITY}

\author{
Putri Novita Taniardi \\ Balai Arkeologi Yogyakarta \\ putri.taniardi@gmail.com
}

\begin{abstract}
The Kekerik ritual has been conducted to celebrate 40 days baby delivery. The ritual is conducted by dukun, a ceremonial leader in Tengger society. This ritual is held to avoid some bad influences from evil spirits arounds. The baby who had this ritual means accepted by Tengger society and start a new life as a holy baby. This kekerik ritual shows megalithic tradition, which is the ancestor spirits is invited to bless the host and also some offerings is made to be presented for the ancestor spirits. The study that conducted in Keduwung village, Puspo district, Pasuruan Regency, East Java Province showed that kekerik ritual reflects megalithic tradition in a Tengger society. This condition is interesting because Tengger people has been known as Hinduneese. The study that define the relation between megalithic tradition and kekerik ritual is applying ethnoarchaeology approach, especially cultural sustainability which assumes that megalithic tradition in Tengger community is related to the past.
\end{abstract}

Keywords: Kekerik Ritual, Tengger, Megalithic Tradition

\begin{abstract}
ABSTRAK
Ritual kekerik diselenggarakan untuk memperingati 40 hari kelahiran bayi. Ritual ini dipimpin oleh seorang dukun selaku pemimpin adat di kalangan masyarakat Tengger. Ritual kekerik bertujuan untuk mengusir pengaruh-pengaruh jahat dari roh-roh di sekitar lingkungan tempat mereka tinggal. Bayi yang telah menjalani ritual ini telah diterima menjadi orang Tengger sepenuhnya dan disucikan jiwanya. Ritual kekerik ini ternyata menunjukkan ciri-ciri tradisi megalitik. Hal ini terlihat pada adanya ritual pemanggilan roh leluhur dan nenek moyang pada saat upacara berlangsung. Roh-roh tersebut disinggahkan pada Sanggar Ayu di Bale Wetan yang disakralkan oleh orang Tengger. Kondisi inilah yang mencerminkan adanya tradisi megalitik pada masyarakat Tengger. Hal ini terungkap pada penelitian yang dilakukan di Dusun Keduwung, Desa Keduwung, Kecamatan Puspo, Kabupaten Pasuruan, Propinsi Jawa Timur. Tradisi megalitik di kalangan masyarakat Tengger ini sangat menarik, mengingat selama ini masyarakat Tengger dikenal sebagai penganut agama Hindu. Untuk itulah, penelitian ini dilakukan, yaitu untuk menggambarkan hubungan antara tradisi megalitik dan ritual kekerik dengan menggunakan pendekatan etnoarkeologi, terutama melalui sudut pandang kesinambungan budaya, yaitu pandangan bahwa tradisi megalitik yang berlangsung di kalangan masyarakat Tengger merupakan perkembangan dari budaya masa lampau.
\end{abstract}

Kata kunci: Ritual kekerik, Tengger, Tradisi megalitik

Tanggal masuk : 22 September 2013

Tanggal diterima : 24 November 2013 


\section{PENDAHULUAN}

Dalam bahasa Jawa kuno, Tengger berarti dataran tinggi. Oleh karena itu, orang-orang yang mendiami dataran tinggi ini disebut wong Tengger (Hefner 1989, 25). Dataran tinggi ini merujuk pada wilayah di lereng Gunung Bromo yang terletak di empat Kabupaten yang meliputi Kabupaten Lumajang, Malang, Probolinggo, dan Pasuruan. Masyarakat yang mendiami lereng Gunung Bromo atau disebut juga sebagai dataran tinggi Tengger dikenal sebagai masyarakat Tengger. Mereka hidup dengan tradisi yang khas secara turun-temurun. Masyarakat Tengger menganut agama Hindu, yang kemudian mereka sebut dengan Hindu Tengger yang berbeda dengan Hindu Bali. Masyarakat Tengger tidak mengenal pembagian kasta seperti halnya Bali dan hidup dalam suasana egaliter. Masyarakat Tengger mengamalkan ajaran agama mereka berdampingan dengan ajaran nenek moyang yang berupa tradisi. Selain memperingati Hari Besar Keagamaan seperti Nyepi, Galungan, dan Kuningan mereka juga melaksanakan ritual seperti Kesadha, Pujan-Pujan, Hari Raya Karo, dan ritual-ritual domestik.

Ajaran nenek moyang yang masih dijalankan hingga sekarang oleh masyarakat Tengger menunjukkan ciri-ciri tradisi megalitik. Masyarakat Tengger meyakini keberadaan roh-roh halus sebagai penjaga kehidupan mereka. Roh halus terkuat yang mereka yakini disebut sebagai Punden. Punden ini bersemayam di Punden Tunggul Sari yang berada di bukit sebelah selatan desa. Punden Tunggul Sari dulunya ditandai dengan batu tegak yang ditengarai sebagai menhir. Pada penelitian yang dilakukan oleh Balai Arkeologi Yogyakarta tahun 2001-2003 diidentifikasi bahwa batu tegak ini adalah menhir yang difungsikan sebagai tempat keramat oleh masyarakat Tengger di Keduwung. Batu tegak ini sekarang sudah tidak tampak lagi karena tertutup oleh bangunan permanen berupa tugu semen. Pengaruh agama Hindu di kalangan Masyarakat Tengger turut berdampak pada pendirian tugu ini. Tugu tersebut berupa padmanyana, yang oleh Umat Hindu digunakan sebagai tempat sembahyang. Punden Tunggul Sari yang kini ditandai dengan padmanyana masih terus dihormati hingga saat ini.

Untuk menuju Punden ini, terdapat tangga atau undak-undakan dari tanah. Gerbang pintu masuk Punden Tunggul Sari ditandai dengan adanya Banaspati yang berupa tugu persegi. Di sebelah utara Banaspati terdapat perabuan, yaitu tempat untuk membakar simbol-simbol bagian tubuh manusia yang dinamakan petra. Simbol-simbol ini terbuat dari daun dan bunga yang menggambarkan mata, mulut,telinga, dan sebagainya. Daun yang digunakan untuk membuat simbol dinamakan daun klokop.

Umat Hindu meyakini bahwa manusia yang sudah meninggal harus dibakar dan abunya dilarung ke laut. Masyarakat Tengger di Keduwung jauh dari laut dan tidak memungkinkan untuk membakar orang yang sudah meninggal dan melarungnya. Untuk itulah, tubuh manusia kemudian digantikan dengan simbol-simbol tersebut dan dipercaya abunya akan sampai ke laut terbawa angin. Pembakaran petra ini merupakan puncak dari upacara entas-entas.

Punden Tunggul Sari merupakan pusat aktivitas masyarakat Tengger, terutama berkaitan dengan ritual yang ditujukan kepada leluhur. Setiap masyarakat Tengger yang mempunyai hajat harus mendatangi Punden Tunggul Sari untuk meminta ijin dan restu. Dalam menyampaikan maksud tersebut, masyarakat Tengger harus melalui dukun adat yang dibantu oleh Sanggar. Seperti misalnya upacara khitanan. Pada waktu malam hari menjelang pelaksanaan khitanan, pemilik hajat mendatangi Punden Tunggul Sari dan mengadakan upacara semeningo. Begitu juga dengan upacara perkawinan dan entas-entas.

Punden Tunggul Sari disosokkan sebagai Danyang laki-laki dan 
berpasangan dengan roh halus penunggu sumber mata air yang disebut dengan Danyang Banyu. Masyarakat Keduwung sangat menghormati keberadaan Punden Tunggul Sari dan Danyang Banyu. Keberadaan keduanya dipercaya sebagai pelindung masyarakat Keduwung. Sebutan bagi Punden Tunggul Sari dan Danyang Banyu kemudian disingkat menjadi Danyang Banyu yang merujuk kepada kedua roh halus pelindung warga Keduwung.

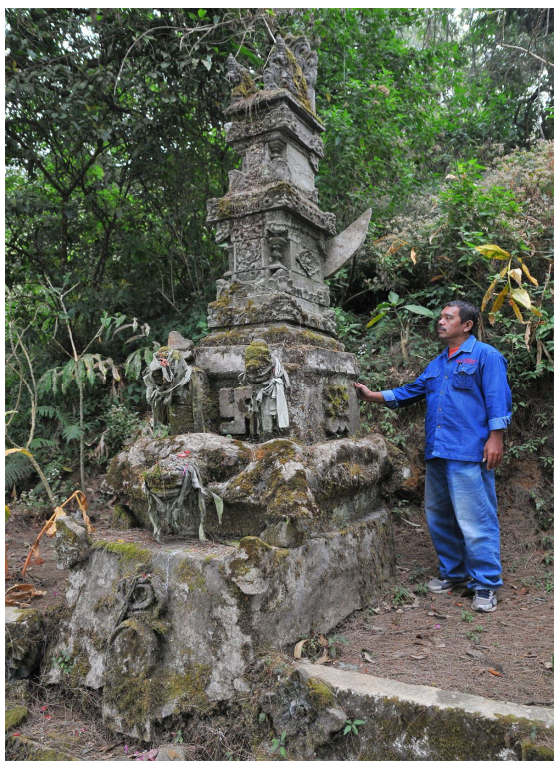

Foto 1. Punden Tunggul Sari

(Dok. Balai Arkeologi Yogyakarta) dukun karena dukun ini merupakan perantara manusia dan roh halus.

Penjaga adat di kalangan masyarakat Tengger adalah dukun-dukun. Setidaknya terdapat tiga jenis dukun, yaitu Dukun Adat, Dukun Umat, dan Dukun bayi. Dukun adat merupakan pemimpin bagi masyarakat Tengger yang bertugas memimpin seluruh upacara keagamaan dan adat dalam lingkup masyarakat Desa. Sementara, dukun umat bertugas memimpin ritual domestik dalam lingkup

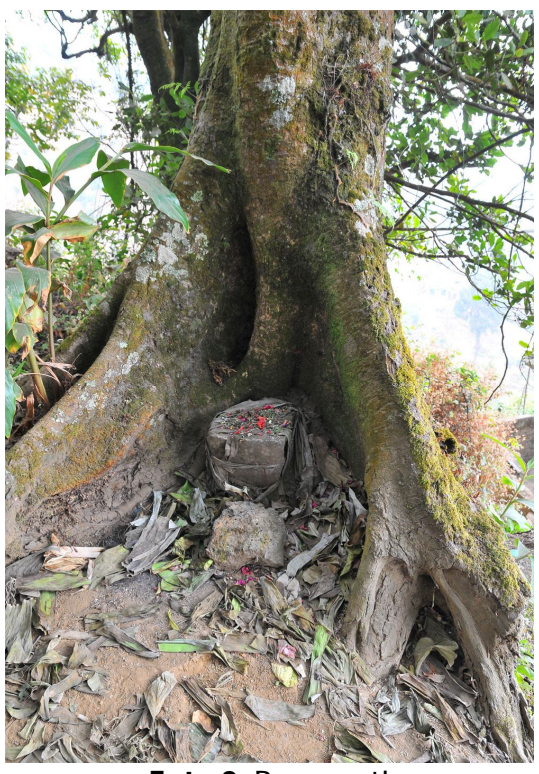

Foto 2. Banaspati

(Dok. Balai Arkeologi Yogyakarta)

keluarga. Dukun bayi bertugas untuk menolong persalinan dan merawat bayi yang baru lahir. Dukun adat memiliki pembantu-pembantu yang semuanya adalah laki-laki dan terdiri atas:

1. Sanggar (pembantu dukun adat)

2. Legen (pembuat sesaji untuk tingkat rumah tangga dan desa)

3. Sepuh (pembuat gambar petra dari tlotoh andong, putihan, tanalayu, senekir, janur, dan pangklung)

Melalui keberadaan para dukun tersebut, masyarakat Tengger menjaga tradisi warisan nenek moyang dengan sungguh-sungguh. Tradisi tersebut diwariskan secara turun-temurun kepada 
anak dan cucu mereka. Hingga saat ini, ritual-ritual domestik maupun adat masih dilaksanakan tanpa terlewatkan. Begitu pula dengan ritual yang berkaitan dengan siklus hidup dari kelahiran hingga kematian. Salah satu ritual yang masih dilaksanakan hingga sekarang adalah ritual kekerik, yaitu ritual domestik untuk menyelamati bayi yang baru berusia 40 hari. Ritual ini dipimpin oleh dukun umat dengan dibantu dukun bayi.

Ritual ini dilaksanakan oleh semua Orang Tengger tanpa terkecuali, begitu pula masyarakat Tengger yang berada di wilayah Pasuruan, seperti misalnya di Dusun Keduwung, Desa Keduwung, Kecamatan Puspo. Ritual ini menunjukkan ciri-ciri tradisi megalitik dalam pelaksanannya. Melihat pentingnya ritual ini, maka tulisan ini berusaha menjawab permasalahan berupa, bagaimana pengaruh tradisi megalitik pada ritual kekerik di kalangan masyarakat Tengger? Sedangkan tujuan dari penulisan karya tulis ini adalah untuk mendeskripsikan pengaruh tradisi megalitik pada pelaksanaan ritual kekerik di kalangan masyarakat Tengger dan menganalisanya melalui studi etnoarkeologi. Untuk menunjang penulisan karya tulis ilmiah ini, dilakukan penelusuran literatur terkait dengan budaya masyarakat Tengger, terutama yang membahas tentang ritual kekerik.

Sebelumnya, tulisan-tulisan tentang masyarakat Tengger telah banyak dibahas oleh para ahli. Misalnya H.J. Wibowo (2003) menulis tentang status dan peranan dukun dalam masyarakat Tengger. Wibowo menggambarkan bagaimana seorang dukun memiliki status yang tinggi di kalangan masyarakat Tengger. Penelitian Wibowo ini dilakukan di Desa Ngadisari, Kecamatan Sukapura, Kabupaten Probolinggo, Jawa Timur. Di Desa Ngadisari ini, dukun yang menjadi subjek penelitian Wibowo merupakan seorang kepala dukun, yaitu pemimpin para dukun. Wibowo menunjukkan bahwa dukun berperan penting dalam memimpin upacara-upacara keagamaan di kalangan masyarakat Tengger. Tulisan Wibowo secara lengkap menggambarkan proses seseorang menjadi dukun, dari ujian hingga pentasbihan, berikut tugas dan tanggung jawab yang diemban oleh seorang dukun.

Tim Peneliti Balai Kajian Sejarah dan Nilai Tradisional Yogyakarta pada tahun 2004 juga telah menerbitkan sebuah buku tentang masyarakat Tengger. Tulisan ini menggambarkan tentang kearifan lokal di lingkungan masyarakat Tengger, Kabupaten Pasuruan, Propinsi Jawa Timur. Tulisan hasil penelitian ini secara lengkap menggambarkan kehidupan masyarakat Tengger di Desa Wonokitri, Kecamatan Tosari, Kabupaten Pasuruan, Propinsi Jawa Timur. Dalam buku ini, digambarkan masyarakat Tengger merupakan masyarakat yang menjaga hubungan dengan alam secara baik. Mereka menyadari bahwa manusia tidak dapat lepas dari alam, bahkan tergantung pada alam untuk memenuhi kebutuhan hidup mereka. Masyarakat Tengger mayoritas bekerja sebagai petani dan sangat tergantung kepada alam. Selain dengan alam, masyarakat Tengger menjalin hubungan baik dengan sesamanya. Hal ini terlihat dalam tradisi bergotong royong di antara mereka.

Pada tahun 2006, Sumarno menulis tentang apresiasi nilai budaya dari cerita rakyat yang hidup di kalangan masyarakat Tengger, terutama masyarakat Tengger di Desa Ngadisari, Kecamatan Sukapura, Kabupaten Probolinggo, Propinsi Jawa Timur. Pelestarian dan apresiasi masyarakat Tengger melalui cerita rakyat tersebut di antaranya pada cerita rakyat asal mula Tengger, Segara Wedhi, Gunung Bathok, Watu Balang, dan Watu Dhukun. Gunung Bathok berkaitan dengan kisah Rara Anteng yang diyakini sebagai nenek moyang orang Tengger. Dikisahkan bahwa karena kecantikannya, banyak lelaki yang berniat melamar Rara Anteng, salah satunya adalah Kyai Bima. Oleh Rara Anteng, lamaran akan diterima jika Kyai Bima mampu membuat lautan dengan cara menggali tanah dengan 
tenpurung. Karena tidak berhasil, Kyai Bima marah dan melempar tempurung kelapa tersebut hingga menajdi sebuah bukit menyerupai tempurung kelapa. Bukit ini terletak di lautan pasir dekat kawah Gunung Bromo. Watu Balang (batu yang dilempar) diyakini terjadi karena amarah Gunung Bromo. Oleh masyarakat setempat, lokasi tersebut diberi pagar dan sanggan. Watu Dhukun diyakini sebagai petilasan pertapa yang mampu menunjukkan jalan bagi setiap orang yang tersesat. Sampai sekarang, petilasan pertapa tersebut yang berupa batu masih dimanfaatkan oleh masyarakat sekitar untuk meletakkan sesaji bagi yang berhasil memenuhi janji dan melimpah hasil panennya. Bentuk apresiasi masyarakat Tengger terhadap cerita rakyat diwujudkan melalui pelaksanaan ritual dalam skala sederhana hingga besar-besaran.

Tahun berikutnya, yaitu pada tahun 2007, Sukari menulis tentang upacara adat di lingkungan masyarakat Tengger. Tulisan ini merupakan hasil penelitian di Desa Wonokitri, Kecamatan Tosari, Kabupaten Pasuruan, Propinsi Jawa Timur. Penelitian Sukari meliputi upacara adat yang berhubungan dengan siklus kehidupan seseorang (daur hidup), upacara adat yang berhubungan dengan lingkungan alam, dan upacara adat yang berhubungan dengan kehidupan masyarakat, yaitu Bujan Mubeng (Pujan Kasanga). Dalam tulisannya, Sukari juga menyinggung tentang upacara kekerik, namun tidak menggambarkan bagaimana upacara tersebut dilaksanakan. Sukari hanya menyebutkan adanya upacara ini sebagai upacara adat dalam masyarakat Tengger.

Pada tahun 2007, Sukari kembali menulis tentang masyarakat Tengger. Tulisan ini mendeskripsikan karakteristik Homestay di daerah tujuan wisata Gunung Bromo-Tengger. Tulisan Sukari ini merupakan hasil penelitiannya di Desa Ngadisari, Kecamatan Sukapura, Kabupaten Probolinggo, Propinsi Jawa Timur. Dalam tulisannya, Sukari mencermati adanya interaksi antara wisatawan dan masyarakat melalui keberadaan homestay. Interaksi tersebut kemudian memunculkan dampak positif dan negatif. Dampak positif yang terlihat adalah meningkatnya perekonomian warga sekitar dari banyaknya homestay yang dihuni, sedangkan dampak negatif yang dirasakan adalah pengaruh latar belakang budaya turis yang datang seringkali diacu oleh pemuda setempat, seperti minum minuman beralkohol dan kata-kata yang tidak pantas.

Pada tahun 2012, J Nicholas Warouw, dkk menuliskan sebuah buku tentang inventarisasi komunitas adat Tengger. Tulisan ini merupakan hasil penelitian di Desa Ngadisari, Kecamatan Sukapura, Kabupaten Probolinggo, Jawa Timur. Buku ini secara cermat menggambarkan kehidupan masyarakat Tengger, mulai dari sejarah hingga ritual dan upacara adat yang dilalaksanakan. Selain itu, dalam buku tersebut juga digambarkan struktur sosial masyarakat Tengger.

Tulisan-tulisan tentang Tengger di atas menggambarkan tentang kehidupan orang Tengger berikut ritual dan tradisinya. Sayangnya, di antara tulisantulisan tersebut belum ada yang menjelaskan tentang ritual kekerik secara khusus. Untuk itulah, gambaran tentang ritual kekerik ini penting untuk dituliskan. Ritual kekerik di kalangan masyarakat Tengger merupakan ritual domestik yang masih menunjukkan ciri-ciri tradisi megalitik. Salah satu cirinya adalah dengan dipujanya roh leluhur pada saat ritual berlangsung. Tulisan ini diharapkan mampu mengungkapkan relasi ritual kekerik dengan tradisi megalitik yang masih hidup di tengah-tengah masyarakat Tengger, sehingga bisa menyumbangkan sebuah pengetahuan baru tentang masyarakat Tengger yang dikenal sebagai penganut agama Hindu yang khas.

Hefner (1989) mengkategorikan selametan ke dalam kategori ritual desa. Pernyataan Hefner ini merujuk pada definisi Geertz tentang selametan. Studi 
Geertz pada masyarakat Mojokutho mencakup ritual peralihan (rite of passage), diantaranya selamatan. Geertz (1983) menyebutkan bahwa selamatan dapat diadakan untuk memenuhi semua hajat orang sehubungan dengan suatu kejadian yang ingin diperingati, ditebus atau dikuduskan. Bagi orang Jawa, selametan penting untuk dilakukan, karena orang tidak merasa dibedakan dengan orang lain. Selain itu, selametan menjaga dari gangguan roh-roh halus (Geertz 1983, 17). Dalam selametan ini, terdapat ritualritual yang menghubungkan antara manusia dengan roh halus yang tidak kasat mata namun dipercaya keberadaannya.

Masyarakat Tengger melaksanakan ritual sebagai bentuk komunikasi dengan roh halus. Pelaksanaan ritual di kalangan masyarakat Tengger menarik untuk dikaji, terutama ritual domestik yang dilakukan dalam lingkup keluarga. Ritual domestik ini seringkali disebut juga dengan istilah selamatan, salah satunya adalah ritual kekerik yang rutin dilakukan oleh orang Tengger bagi bayi yang berusia 40 hari. Penelitian tentang selametan ini dlakukan di Dusun Keduwung, Desa Keduwung, Kecamatan Puspo, Kabupaten Pasuruan, Propinsi Jawa Timur. Penelitian ini merupakan penelitian penyerta bagi penelitian yang berjudul "Arsitektur Candi Sanggar Fungsi dan Komponennya." Pengumpulan data dilakukan dengan mengadakan observasi objek, wawancara mendalam terhadap informan kunci, yaitu pelaku ritual kekerik yang meliputi orang tua bayi, dukun umat, dan dukun bayi. Supaya seluruh rangkaian ritual kekerik tidak terlewatkan, dilakukan juga observasi selama ritual berlangsung. Setelah semua data terkumpul, kemudian dilakukan analisis dengan pendekatan etnoarkeologi dengan cara mendeskripsikan kesinambungan budaya, yaitu adanya tradisi megalitik yang masih berlangsung hingga sekarang dipandang sebagai kelanjutan budaya masa lampau.

Studi etnoarkeologi di Indonesia telah berkembang sejak tahun 1970-an.
Studi etnoarkeologi di Indonesia dinilai dapat memainkan peran ganda, yaitu selain sebagai sarana dalam menjelaskan dan menafisrkan data arkeologi, juga untuk mendokumentasikan aspek-aspek kehidupan tradisional yang masih berlangsung (Tanudirdjo 1987, 9). Studi etnoarkeologi sendiri pada dasarnya bertujuan untuk menjembatani kesenjangan antara data arkeologi yang ditemukan dengan tingkah laku yang menyebabkannya berdasarkan dengan gejala di masa kini (Tanudirdjo 1987, 3). Carol Kramer $(1979,1)$ mendeskripsikan etnoarkeologi sebagai:

Ethnoarchaeological research
investigates aspects of
contemporary sociocultural
behaviour from an archaelogical
perspective; ethnoarchaeologist
attemp to systematically define
relationship between behaviour and
material culture not often explored by
ethnologist, and to ascertain how
certain features of obsrvable
behaviour may be reflected in
remains which archaelogist may find.

Melalui penjabaran Kramer mengenai etnoarkeologi tersebut terlihat bahwa tujuan studi etnoarkeologi salah satunya adalah untuk mendefinisikan hubungan antara perilaku dan budaya materi yang belum diungkap oleh ahli etnologi. Studi etnoarkeologi memiliki kerangka syarat yang telah diletakkan oleh Ascher dengan menyebutkan dua model pendekatan dalam studi etnoarkeologi, yaitu pendekatan kesinambungan sejarah (direct historical) dan perbandingan umum (general comperative). Pendekatan pertama didasari bahwa budaya yang ada sekarang merupakan perkembangan dari budaya masa lampau, sehingga ciri budaya yang ada sekarang merupakan warisan dari budaya yang telah berkembang sebelumnya. Sementara itu, pendekatan perbandingan umum didasari dengan pandangan bahwa hubungan antara budaya arkeologi yang 
pemdukungnya telah punah dengan budaya yang masih berlangsung pada hakikatnya adalah hubungan bentuk, sehingga tidak perlu mempunyai kaitan sejarah, ruang maupun waktu (Tanudirdjo 1983, 32).

Studi etnoarkeologi sesuai penjabaran Kramer inilah yang diterapkan pada studi etnoarkeologi masyarakat Tengger. Fokus studi tersebut pada unsur megalitik yang terdapat pada ritual kekerik. Studi ini mengungkap bagaimana unsurunsur megalitik tersebut tercermin melalui perilaku-perliku ritual masyarakat Tengger. Benda arkeologi yang terdapat di tengahtengah masyarakat Tengger berupa menhir yang sudah tidak tampak lagi wujudnya, namun diperbaharui dengan bangunan baru. Bangunan tersebut dikenal sebagai punden dan sampai sekarang diyakini sebagai tempat bersemayamnya roh halus yang paling dihormati oleh masyarakat Tengger, terutama di Dusun Keduwung. Studi etnoarkeologi ini menghubungkan masyarakat Tengger masa kini dengan benda arkeologi yang ada jauh sebelum mereka dilahirkan namun masih dimaknai hingga sekarang ini.

\section{RITUAL-RITUAL MASYARAKAT TENGGER}

Masyarakat Tengger merupakan masyarakat penganut agama Hindu yang taat, namun agama Hindu tersebut berbeda dengan agama Hindu yang dianut oleh masyarakat Bali. Masyarakat Tengger masih melaksanakan ritual-ritual adat warisan nenek moyang di samping ajaran agama yang mereka anut. Mereka meyakini bahwa ajaran nenek moyang yang menempatkan roh-roh halus dalam kedudukan penting harus dilestarikan. Bagi mereka, roh-roh halus adalah pelindung yang sekalipun tidak kasat mata, namun keberadaannya dapat dirasakan. Roh halus tertua dan dituakan yang ada di Dusun Keduwung mereka yakini bersemayam di Punden, sebutaan masyarakat Tengger bagi roh halus tersebut. Punden tertua tersebut dikenal sebagai Punden Tunggul Payung, sedangkan roh yang bersemayam di tempat tersebut dikenal sebagai Raden Bagus Tunggul Sari. Punden Tunggul Payung terletak di bukit kecil selatan desa yang berupa undakan tiga teras. Sebagai pintu masuk atau tingkatan pertama terdapat penanda dari bata untuk meletakkan tamping (sesaji) setiap ada selamatan. Penunggu tempat ini adalah roh leluhur yang tidak diketahui namanya. Tingkatan kedua berupa Banaspati. Tempat ini merupakan lokasi pembakaran petra (simbol anggota tubuh manusia yang dibuat dari dedaunan dan bunga) pada upacara entas-entas (ritual kematian pada 1000 hari orang meninggal). Penanda Banaspati berupa pohon dan Jaka Mesir merupakan roh yang bersemayam di tempat ini. Tingkatan ketiga atau paling inti adalah punden. Dulunya, orang Keduwung meletakkan pohon atau kayu atau batu sebagai "tetenger". Pada tahun 2003 masih ditemui batu tegak menyerupai menhir sebagai penanda punden ini. Sekarang, sebuah bangunan permanen berupa padmanyana didirikan sebagai penanda punden ini. Di punden inilah Raden Bagus Tunggul Sari bersemayam. Sebuah krapyak yang terbuat dari bambu sengaja diletakkan di sini sebagai pelindung dari binatang yang akan merusak sesaji.

Bentuk penghormatan masyarakat Tengger terhadap roh-roh halus diaplikasikan dalam pelaksanaan berbagai di dalam kehidupan mereka sehari-hari. Ritual tersebut biasanya untuk menyelamati kejadian-kejadian seputar siklus hidup manusia, dari kelahiran hingga kematian. Begitu pula masyarakat Tengger yang tinggal di Dusun Keduwung. Ritual-ritual tersebut tidak ada yang dilewatkan dan dilaksanakan sebagai sebuah bagian dari hidup mereka. Ritual yang terkait dengan siklus kehidupan tersebut di antaranya:

1. Pada saat seorang perempuan tengah hamil pada usia kandungan tujuh bulan, diselenggarakan selamatan sayut 
2. Pada saat bayi sudah dilahirkan dan berusia bayi 40 hari diadakan selamatan kekerik

Baik selamatan sayut maupun selamatan kekerik dipimpin oleh dukun umat

3. Sunat

Untuk prosesi sunat ini biasanya dipimpin oleh dukun adat, baik sebagai pemimpin selamatan maupun sebagai penyunat sendiri. Pada selamatan nyunat ini biasanya dilengkapi dengan sesaji yang berupa:

a. Jenang abang dan jenang putih

b. Sego golong

c. Tumpeng kebuli

d. Beras sepitrah yang terdiri atas beras, pisang, kelapa, gula batu 10 keping, epras (pisang, tumpeng, jadah, pasung atau kukusan tepung, pipis atau sejenis panganan, ketan putih, dan panggang ayam.

Pada selamatan nyunat ini biasanya diselenggarakan pula ritual tugel kuncung, yaitu potong rambut sejumlah tiga kali. Tugel kuncung dilaksanakan sebelum prosesi nyunat dimulai.

4. Kawin

Pada prosesi kawin, Dukun adat bertugas sebagai pemimpin mantra sesaji. Sedangkan yang bertugas menikahkan adalah ketua Parisadha.

Japamantra :

Hong Pakulun

Ndugekaken hajat niate Bapak...lan mbok...

Nggadahi niat ngawinaken utawi imah-imahaken yugane jaler estri ingkang namine jaler...estri...

Mugi-mugi dipun paringi rahayu wilujeng ampun wonten ingkang ganggu resiko mbeda rencana

Ampun wonten ingkang nggodha nyengkala

Adohaken balak braine

Cedakaken rejekine

Salamikum salam

5. Orang meninggal

Orang yang meninggal dimandikan oleh Sanggar dengan air yang telah dimantrai sebanyak tiga kali guyuran. Setelah itu dibungkus dengan lawon, tikar, dan terakhir dimasukkan ke kotak trebelo. $\mathrm{Di}$ dalam trebelo ini dimasukkan klakah (bambu), seng, sirap, dan plupuh sebagai simbol rumah orang hidup. Harapannya. Orang yang telah meninggal telah mempunyai rumah di kehidupan selanjutnya. Setelah dikuburkan, di atas pusara diletakkan payung yang bertujuan untuk meneduhi, kerek (bambu) sebagai jalan pernapasan, pisang ayu sebagai pelinggihan sukma nyawa, kembang boreh sebagai penerang jalan ke surga, palawija (jagung,bawang, kubis, dan kentang) sebagai pesangon. Setelah itu didoakan oleh Sanggar, kemudian petra orang meninggal tersebut dibawa ke perabuan untuk dibakar. Selamatan orang meninggal sampai pada hari ke tujuh dan diakhiri dengan upacara entas-entas. Entas-entas ini biasanya tidak lebih dari 1000 hari setelah orang meninggal agar orang tersebut dapat segera menuju surga.

Ritual-ritual tersebut selalu melibatkan dukun, baik dukun umat maupun dukun adat sebagai pemimpin ritual. Dalam setiap ritual juga tidak boleh sampai melewatkan pembuatan sesaji yang ditujukan kepada Danyang dan para roh halus. Begitu pula ritual domestik yang selalu dilaksanakan oleh masyarakat Tengger di Dusun Keduwung. Salah satunya adalah kekerik untuk menyelamati kelahiran bayi pada usia 40 hari. Oleh masyarakat Tengger, ritual ini dikenal sebagai selamatan kekerik. Ritual ini dilaksanakan pada lingkup keluarga dengan melibatkan keluarga besar yang tinggal di sekitar rumah orang tua bayi. Selamatan wajib dilaksanakan bagi semua orang tua yang memiliki bayi. Pelaksanaan selamatan ini biasanya berlangsung selama tiga hari. Hari pertama ditandai dengan aktivitas memasak oleh ibu-ibu di dapur sebagai persiapan puncak acara selamatan. Pada hari kedua, diadakan 
kenduri bagi para bapak dan ibu yang dilaksanakan secara terpisah. Peserta kenduri hanya tetangga sekitar rumah saja. Pada hari ketiga, atau puncak acara selamatan kekerik, seluruh keluarga besar berkumpul di rumah orang tua bayi. Para perempuan memasak keperluan pembuatan sesaji di dapur sebagai persiapan ritual. Sementara para perempuan memasak, para lelaki berkumpul di ruang depan sambil berbincang-bincang, merokok, dan memakan kudapan yang dihidangkan. Kudapan-kudapan ini seluruhnya dimasak oleh para perempuan yang telah beraktivitas di dapur tiga hari sebelumnya. Pada saat selamatan kekerik ini, keriuhan orang-orang hanya tampak pada rumah penyelenggara selamatan. Begitu pula dengan orang-orang yang berpartisipasi, hanya khusus untuk keluarga besar.

Pada puncak acara ritual, dukun umat dan dukun bayi sudah bersiap sejak pagi. Dukun bayi memang masih bertugas merawat bayi dari sejak bayi dilahirkan. Terlebih bagi perempuan yang baru memiliki anak pertama. Peran dukun bayi sangat penting, selain merawat bayi juga mengajari si ibu dalam merawat anaknya. Dukun umat bertugas untuk memantau persiapan ritual, termasuk kelengkapan sesajinya. Pada ritual kekerik ini ada beberapa sesaji yang harus disiapkan, diantaranya:

1. Pras Kerik yang berisi tumpeng sebanyak dua buah, jadah, pasung, pipis (jajan pasar), ketan, janganan (sayur). Pras kerik menyimbolkan anak bayi yang masih ada di dalam kandungan dan belum melihat terangnya dunia.

2. Pras Padhang awan yang isinya sama seperti Pras Kerik, menyimbolkan bayi yang sudah melihat terangnya siang hari

3. Pras abang-putih yang ditujukan untuk menyelamati proses melahirkan di dalam kamar

4. Pras Pulo Sekalangan yang menyimbolkan supaya tidak ada halangan bagi bayi dan orangtuanya
5. Sesaji yang ditujukan untuk menyelamati Danyang Banyu berisikan nasi gurih dan gubahan, serta tamping (sesaji)

6. Tumpeng Agung yang berisi jenang abang dan putih, sega golong, dan sega kabuli. Sesaji ini dibuat dengan tujuan supaya terkabul hajatnya

7. Sekul anget yang bertujuan untuk menyelamati orang yang menolong melahirkan dan di dalamnya ada sesaji tersendiri

8. Tumpeng Brosot yang bertujuan menyelamati waktu "mbrojol" atau proses melahirkan

9. Gedhang ayu yang terdiri atas pisang, sirih, boreh (bunga), dan uang persembahan. Gedhang ayu ini merupakan pelinggih, atau tempat persemayaman roh leluhur yang sengaja diundang selama ritual berlangsung

10. Pring yang berisi beras, kunyit, dan lawe yang dinamakan tebus

11. Mangkok yang berisi air dan daun pisang untuk memercik, bertujuan untuk menyucikan sarana sesaji sebelum dipersembahkan kepada rohroh halus

12. Sebagai pelengkap seluruh sesaji adalah panggang ayam yang diletakkan bersama Pras Panggang Ayam

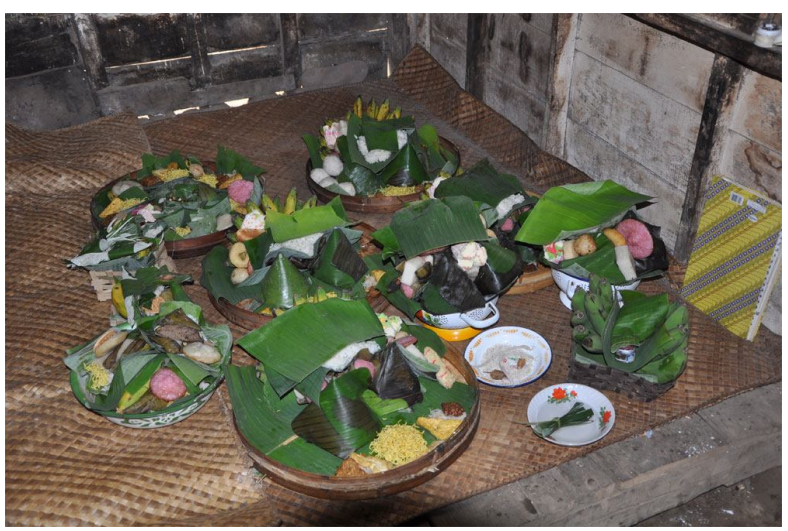

Foto 3. Sesaji

(Dok. Balai Arkeologi Yogyakarta) 


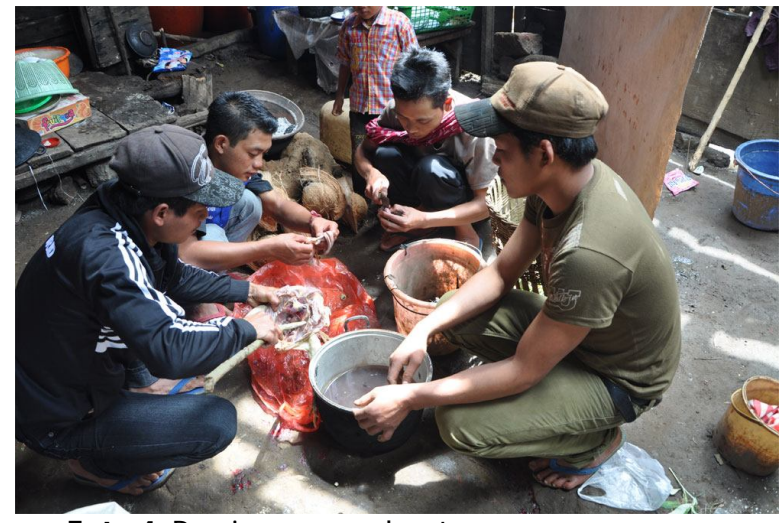

Foto 4. Persiapan membuat panggang ayam (Dok. Balai Arkeologi Yogyakarta)

Seluruh sesaji tersebut ditata pada ruang tamu di sisi timur atau dalam tata ruang Tengger dinamakan Bale Wetan. Di sisi barat ruang tamu terdapat meja panjang yang penuh berisi makanan, dari mulai nasi, sayur, hingga lauk pauk. Semua hidangan tadi ditata sepanjang meja dan diperuntukkan bagi tamu-tamu yang datang selama selamatan berlangsung.

Setelah panggang ayam selesai dimasak, seluruh sesaji sudah lengkap maka ritual siap dimulai. Markasan (40) selaku dukun umat kemudian memanggil orang tua bayi dan menyuruh si ibu untuk menggendong anaknya. Ibu tersebut selalu didampingi oleh Mbok Arwati (50) selaku dukun bayi.

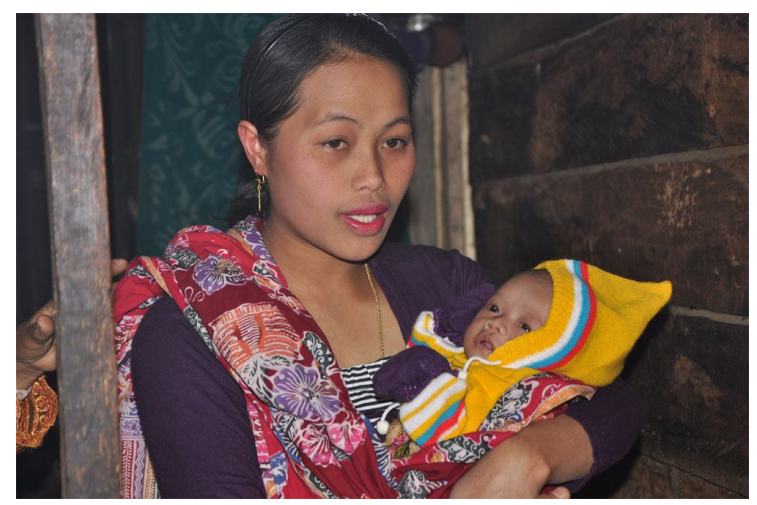

Foto 5. Ibu dan bayi yang diselamati (Dok. Balai Arkeologi Yogyakarta)

Markasan kemudian duduk menghadap sisi selatan sekaligus seluruh sesaji tersebut dan bersiap memulai ritual.
Kemenyan segera dinyalakan sambil melantunkan japamantra. Mangkok yang berisi air suci selalu dipegang oleh Markasan. Setiap selesai merapalkan japamantra, air suci tersebut kemudian dipercikkan ke arah sesaji-sesaji. Hal ini dilakukan berulang-ulang hingga seluruh japamantra selesai dirapalkan.

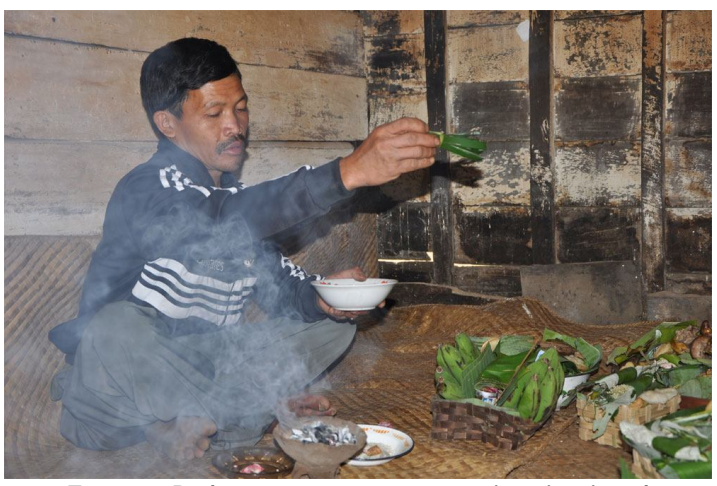

Foto 6. Dukun umat yang memimpin ritual (Dok. Balai Arkeologi Yogyakarta)

Dukun umat tersebut kemudian memanggil ibu bayi untuk mendekat dan menyodorkan sirih pinang untuk dikunyah. Kunyahan sirih pinang kemudian diludahkan sebanyak tiga kali ke dalam boreh lalu dioleskan kepada semua orang yang menolong pada saat proses melahirkan, seperti misalnya dukun bayi, suaminya, serta tetangga sekitar. Tujuan dari diolesi boreh tersebut adalah untuk memohon keselamatan bagi orang-orang yang sudah menolong melahirkan. Selesai mengoleskan boreh, welat (bilah bambu) yang digunakan untuk memotong pusar bayi kemudian disucikan. Setelah itu, lawe yang telah dijapamantra diikatkan ke tangan bayi dan tidak boleh dilepaskan oleh siapapun. Lawe ini harus lepas dengan sendirinya seiring berjalannya waktu. Dengan diikatkannya lawe, berarti bayi tersebut sudah disucikan dengan ikatan lawe sebagai tetenger (penanda). Puncak ritual kekerik adalah pelepasan ayam iber-iber di pintu rumah. Ayam ini dilepaskan oleh ayah bayi dengan melewatkan ayam di antara rentangan kaki ibu bayi ke arah ke luar rumah. Pelepasan ayam iber-iber ini untuk 
menyucikan jalan lahir bayi dan menyimbolkan kelancaran proses melahirkan. Setelah seluruh rangkaian ritual selesai, sesaji yang ditujukan kepada Danyang Banyu segera disiapkan untuk kemudian dilakukan tetamping (mempersembahkan sesaji). Sesaji lainnya kemudian dikukuti (diberesi) dan diserahkan kepada dukun umat dan dukun bayi. Sesaji ini dinamakan sisayadnya.

\section{KEKERIK DALAM KONTEKS RITUAL}

Koentjaraningrat (1972, 243-244) mendefinisikan ritual sebagai upacara keagamaan. Secara spesifik, Koentjaraningrat menjabarkan upacara keagamaan sebagai kelakuan keagamaan yang dilakukan menurut tata kelakukan yang baku. Upacara keagamaan dapat terbagi menjadi empat komponen, yaitu:

1. tempat upacara,

2. saat upacara,

3. benda-benda dan alat-alat upacara,

4. orang-orang yang melakukan dan memimpin upacara

Pada ritual domestik di masyarakat Tengger, tempat upacara keagamaan atau ritual biasanya di rumah tempat tinggal penyelenggara ritual. Pada upacara kekerik ini misalnya, tempat menyelenggarakan selamatan di rumah orang tua bayi. Senada dengan deskripsi Koentjaraningrat tentang tempat upacara, ia menggambarkan bahwa pada upacara keagamaan yang dilakukan di rumah, dipilih sebuah tempat yang dianggap paling pokok dari seluruh ruang di rumah tersebut. Masyarakat Tengger memiliki konsep tata ruang yang sinergis dengan kepercayaan yang mereka anut. Bale wetan yang berada di ruang tamu selalu menjadi tempat pokok untuk meletakkan sesaji-sesaji pada semua ritual domestik. Bale Wetan ini berada di bawah Sanggar Agung, tempat yang diyakini sebagai pelinggih atau tempat bersemayamnya roh-roh leluhur. Saat upacara merupakan komponen yang juga penting dalam menyelenggarakan upacara keagamaan. Koentjaraningrat mencontohkan saat upacara ini pada kondisi dimana keadaan sudah genting dan mendesak untuk dilakukan upacara keagamaan. Hal ini tidak selalu berlaku pada masyarakat Tengger, di mana dalam kepercayaan masyarakat Tengger mereka mengenal ritual desa (komunal) dan ritual domestik. Ritual domestik sendiri berkaitan dengan siklus hidup manusia dan ditujukan sebagai sebuah bentuk selamatan atau menghindarkan dari gangguan roh-roh halus. Pada upacara kekerik, sudah ada ketentuan yang pasti perihal pelaksanaan selamatan, yaitu pada saat bayi berusia 40 hari. Waktu pelaksanaan selametan ini tidak dapat ditunda karena bayi harus disucikan dan ditebus untuk menghindari gangguan dari roh-roh alus tersebut.

Benda-benda upacara harus ada pula dalam setiap upacara keagamaan. Koentjaraningrat mendefinisikan bendabenda upacara sebagai alat-alat yang dipakai dalam menjalankan upacaraupacara keagamaan. Pada selamatan kekerik, benda-benda upacara tidak banyak digunakan. Benda penting yang harus ada dalam ritual kekerik adalah kemenyan dan air suci. Terakhir, komponen pokok yang harus ada pada upacara keagamaan adalah orang-orang yang melakukan upacara. Koentjaraningrat mencontohkan orangorang yang melakukan upacara ini seperti misalnya pendeta, dukun, dan syaman. Masyarakat Tengger menempatkan dukun dalam posisi yang penting dalam kehidupan mereka. Baik dukun adat maupun dukun umat merupakan tokoh yang dihormati. Ritual-ritual domestik biasanya dipimpin oleh seorang dukun umat. Dukun ini bertugas memimpin seluruh jalannya ritual, mulai dari persiapan hingga pelaksanaan.

Ritual kekerik bertujuan untuk menyucikan bayi, karena bayi yang dilahirkan masih dalam keadaan kotor dan rentan dari pengaruh roh-roh jahat. Selain itu, bayi tersebut juga harus ditebus oleh orangtuanya melalui ritual kekerik ini. Dengan menjalani ritual kekerik, bayi tersebut sudah dalam keadaan suci dan 
dapat diterima di tengah-tengah masyarakat Tengger. Untuk itu, selain sebagai fungsi ritual yang menyucikan, kekerik juga menandai sebuah proses inisiasi peralihan, dari bayi yang belum diakui secara adat menjadi bagian dari masyarakat Tengger dan menjadi orang Tengger seutuhnya.

\section{UNSUR TRADISI MEGALITIK PADA RITUAL KEKERIK}

Tradisi megalitik identik dengan tradisi pendirian bangunan-bangunan megalitik (mega berarti besar, lithos berarti batu) yang selalu dihubungkan dengan kepercayaan adanya hubungan antara yang hidup dan mati. Berdasarkan bentuk peninggalannya, tradisi megalitik dapat dibedakan menjadi dua, yaitu megalitik tua (older megalithic) dan megalitik muda (younger megalitik). Megalitik tua biasanya ditandai dengan bentuk menhir, dolmen, teras berundak, dan batu datar. Sedangkan megalitik muda ditandai dengan bentuk arca, sarkofagus, keranda batu, kubur peti batu, dan lain-lain. Megalitik dari masa prasejarah ditemukan di daerah Pasemah (Sumatra Selatan), Gunungkidul (Yogyakarta), Matesih (Surakarta), Bondowoso (Jawa Timur), dan lain-lain. Sedangkan tradisi megalitik yang masih berlanjut ditemukan di daerah Nias, Toraja, Sumba, Sabu, Flores, dan Timor (Prasetyo \& Yuniawati 2004, 110).

Pendapat yang berbeda dilontarkan oleh F.A. Wagner terkait pengertian tradisi megalitik tersebut. la menyatakan bahwa megalit yang diartikan sebagai "batu besar" di beberapa tempat akan membawa konsep yang keliru. Objekobjek batu yang lebih kecil dan bahanbahan lain seperti kayu pun harus dimasukkan ke dalam klasifikasi megalit jika dipergunakan sebagai sarana pemujaan nenek moyang (Pusponegoro \& Notosusanto 2008, 250).

Pernyataan Wagner ini dapat diterapkan pada kondisi yang ada di kalangan masyarakat Tengger. Mereka masih memuja roh-roh leluhur dan nenek moyang melalui upacara adat dan ritualritual domestik. Meskipun mereka menganut agama Hindu, kepercayaan terhadap nenek moyang tidak dapat ditinggalkan. Bahkan, keberadaan nenek moyang ini sangat dihormati dan dijadikan pelindung bagi keselamatan warga, karena mereka berada di tengah-tengah mereka. Roh leluhur desa mereka yakini bersemayam di Punden Tunggul Sari yang setiap saat dapat mereka kunjungi. Ritual domestik seperti kekerik merupakan contoh nyata di mana roh leluhur ini sangat dihormati. Pada pembacaan japamantra, nama roh leluhur harus disebutkan dan dipanggil dan didudukkan di Sanggar Agung pada Bale Wetan untuk memberi restu pada penyelenggara ritual. Jika hal ini sampai dilupakan, akan ada kejadian buruk yang menimpa mereka. Masyarakat Tengger mempunyai kepercayaan yang erat terkait dengan arah timur. Mereka percaya bahwa arah timur merupakan simbol ketuaan, di mana matahari terbit. Semua perhitungan penanggalan di Tengger selalu diawali dari arah timur. Penerapan arah timur sebagai arah yang pacet (tetap) dan disakralkan diaplikasikan dalam berbagai aspek masyarakat Tengger. Salah satunya dalam penentuan tata ruang sebuah rumah.

Masyarakat Tengger mempunyai patokan dalam pembuatan rumah yang telah diwariskan secara turun temurun. Sehingga, walaupun saat ini sudah tidak ada rumah asli adat Tengger yang masih bertahan, konsep-konsep tata ruang tersebut masih digunakan. Seperti misalnya adanya larangan untuk arah hadap dapur, yaitu menghadap ke timur. Kepercayaan ini diwariskan turun-temurun antargenerasi dan tidak pernah ditinggalkan. Inilah tradisi megalitik yang mereka jalankan hingga saat ini. Unsur megalitik pada masyarakat Tengger juga tampak pada ritual kematiannya. Orang Tengger dimakamkan dengan posisi kepala berada di sebelah selatan dan menghadap utara. Arah utara yang merupakan letak Gunung Bromo 
dipercaya sebagai surga masyarakat Tengger, sehingga semua orang yang meninggal akan menuju surga.

Penghormatan terhadap arah timur ini mirip dengan konsep The Children of The Sun yang dianut oleh masyarakat Toraja, yaitu tentang keberadaan Raja Matahari yang hadir di tengah-tengah mereka. Arah terbit matahari, yaitu arah Timur juga mereka sakralkan. Di Indonesia, kebudayaan kuno identik dengan penggunaan konsep The Children of The Sun, di mana arah terbitnya matahari diyakini sebagai tempat yang sakral dan sebagai asal mula kehidupan (Perry 1923, 135). Selain arah timur, keberadaan Gunung Bromo juga merupakan tempat sakral bagi masyarakat Tengger. Mereka meyakini bahwa Gunung Bromo merupakan tempat bersemayamnya roh halus penjaga masyarakat Tengger, terkait dengan mitos Roro Anteng dan Jaka Seger yang mengorbankan putra mereka ke kawah Tengger. Roh putra Rara Anteng dan Jaka Seger itulah yang mereka yakini sebagai pelindung masyarakat Tengger.

Gunung yang disucikan tidak hanya menjadi budaya masyarakat Tengger, masyarakat Bali pun menganut kepercayaan serupa. Gunung tersebut mengalirkan mata air yang menyuburkan lahan pertanian mereka, sehingga masyarakat bali sangat menyakralkannya. Miniatur gunung tersebut diaplikasikan dalam pembangunan pura tempat mereka bersembahyang (Wales 1958, 123).

Baik arah timur maupun penghormatan terhadap gunung merupakan kebudayaan kuno yang ada jauh sebelum masa Hindu. Kebudayaan ini mencerminkan religi manusia kala itu dalam menerjemahkan keberadaan Tuhannya. Sebagai masyarakat yang telah menganut agama Hindu, masyarakat Tengger rupanya masih mempertahankan kebudayaan kuno yang ada jauh sebelum agama Hindu tersebut ada. Kebudayaan tersebut terus mereka pertahankan hingga saat ini dan diwariskan secara turuntemurun. Kondisi ini semakin menguatkan adanya unsur megalitik pada masyarakat Tengger yang juga diaplikasikan pada ritual sehari-hari, termasuk pada ritual kekerik.

\section{PENUTUP}

Ritual kekerik pada masyarakat Tengger diperuntukkan bagi bayi yang berusia 40 hari. Ritual ini bertujuan untuk menyelamati bayi dan menyucikannya. Ritual kekerik dilaksanakan di rumah tempat tinggal sang bayi, sehingga masuk dalam kategori ritual domestik. Pelaksanaan ritual dipimpin oleh seorang dukun umat. Dukun umat ini juga bertugas untuk memantau seluruh persiapan ritual, seperti sesaji dan benda-benda yang digunakan untuk menjalankan ritual. Pada saat ritual kekerik berlangsung, ibu si bayi didampingi oleh dukun bayi yang bertugas merawat bayi dari mulai lahir. Dukun bayi ini pula yang menolong pada saat proses kelahiran.

Ritual ini melibatkan keluarga besar orang tua bayi yang diramaikan oleh orang-orang sekitar tempat tinggal orang tua bayi dan masih memiliki hubungan kekerabatan. Selamatan kekerik merupakan ritual wajib yang harus dilakukan oleh orang Tengger sebagai salah satu ritual dalam siklus hidup manusia.

Ritual kekerik menunjukkan unsur tradisi megalitik yang hidup di tengahtengah masyarakat Tengger. $\mathrm{Hal}$ ini tampak pada pemberian sesaji kepada roh halus yang bersemayam di Punden Tunggul Sari yang mereka yakini sebagai pelindung masyarakat Tengger. Punden tersebut dulunya berupa batu menyerupai menhir yang telah ditutup bangunan permanen. Unsur megalitik yang juga tampak pada masyarakat Tengger adalah penghormatan arah timur sebagai arah yang dituakan dan dijadikan patokan bagi orang Tengger. Selain itu, masyarakat Tengger juga menyakralkan Gunung Bromo yang berada di utara Dusun Keduwung. arah utara ini menjadi orientasi penguburan mayat pada ritual kematian. 
Unsur-unsur megalitik pada masyarakat Tengger ini menunjukkan bahwa aspek religi dapat hidup berdampingan, melalui koridor agama dan tradisi.

\section{UCAPAN TERIMA KASIH}

Penulis mengucapakan terima kasih kepada Drs. T.M. Hari Lelono selaku ketua tim yang telah mengijinkan penulis untuk melakukan penelitian penyerta ini. Terima kasih juga penulis sampaikan kepada Misrani selaku orang tua bayi, Markasan selaku dukun umat, Mbok Arwati selaku dukun bayi, dan Panjoyo selaku informan kunci. 


\section{DAFTAR PUSTAKA}

Geertz, Clifford. 1983. Abangan, Santri, Priyayi dalam Masyarakat Jawa. Jakarta: Pustaka Jaya

Hefner, Robert W. 1989. Hindu Javaneese, Tengger Tradition and Islam. UK: Princenton University Press

Koentjaraningrat. 1985. Beberapa Pokok Antropologi Sosial. Jakarta: Dian Rakyat

Kramer, Carol. 1979. Introduction dalam Ethnoarchaelogy, Implications of Ethography for Archaeology. New York: Columbia University Press

Perry, W.J. 1923. The Children of The Sun. London: Methuen \& Co. Ltd

Prasetyo, Bagyo dan Dwi Y Yuniawati (ed.). 2004. Religi pada masyarakat Prasejarah Di Indonesia. Jakarta: Kementrian Kebudayaan dan Pariwisata

Pusponegoro, Marwati D dan Nugroho Notosusanto (ed.). 2008. Sejarah Nasional Indonesia I (Edisi Pemutakhiran). Jakarta: Balai Pustaka

Sukari. 2007. "Upacara Adat di Lingkungan Masyarakat Tengger" dalam Patrawidya Vol. 8 No. 4 Desember 2007. Yogyakarta: Balai Pelestarian Sejarah dan Nilai Tradisional. HIm. 803-843

Sukari. 2009. "Karakteristik Homestay di Daerah Tujuan Wisata Gunung Bromo Tengger" dalam Patrawidya Vol. 10 No. 2 Juni 2009. Yogyakarta: Balai Pelestarian Sejarah dan Nilai Tradisional. HIm. 459-494

Sumarno. 2006. "Apresiasi Nilai Budaya dari Cerita Rakyat yang Hidup di Kalangan Masyarakat Tengger" dalam Patrawidya Vol. 7 No. 1 Maret 2006. Yogyakarta: Balai Pelestarian Sejarah dan Nilai Tradisional. HIm. 281-317

Tanudirdjo, Daud Aris. 1987. Laporan Penelitian Penerapan Etnoarkeologi di Indonesia. Yogyakarta: Fakultas Sastra Universitas Gadjah Mada

Tim Peneliti BPSNT Yogyakarta. 2004. Kearifan Lokal di Lingkungan Masyarakat Tengger, Kabupaten Pasuruan, Propinsi Jawa Timur. Yogyakarta: Balai Pelestarian Sejarah dan Nilai Tradisional

Tim Penelitian Balai Arkeologi Yogyakarta. 2012. "Bentuk Permukiman, Rumah dan Latar Kepercayaan Suku Tengger di Jawa Timur" dalam Laporan Penelitian Arkeologi. Tidak diterbitkan.

Wales, H.G. Quaritch. 1958. The Mountain of God. London: Bernard Quaritch,Ltd

Warouw, J. Nicholas, dkk. 2012. Inventarisasi Komunitas Adat Tengegr Desa Ngadisari, Kecamatan Sukapura, kabupaten Probolinggo, Jawa Timur. Tidak diterbitkan. 
Wibowo, H J. 2003. "Status dan Peranan Sosial Dukun dalam Masyarakat Tengger" dalam Patrawidya Vol. 4 No.1 Maret 2003. Yogyakarta: Balai Pelestarian Sejarah dan Nilai Tradisional. HIm. 177-222 